\title{
RREB1 Gene
}

National Cancer Institute

\section{Source}

National Cancer Institute. RREB1 Gene. NCI Thesaurus. Code C140254.

This gene is involved in binding to RAS-responsive elements (RRES) in the promoters of target genes. 